\title{
Changes in the pattern of health beneficial omega 3 fatty acids during processing of sardine fish curry
}

\author{
R. SHALINI, R. JEYA SHAKILA, M. PALANI KUMAR AND G. JEYASEKARAN \\ Fisheries College and Research Institute, Thoothukudi - 628 008, Tamil Nadu, India \\ e-mail: shalinimispa@gmail.com
}

\begin{abstract}
Sardine curry, a traditional Indian dish was prepared from Sardinella gibbosa (Bleeker, 1849) to examine the changes in fatty acid composition particularly of the omega 3 fatty acids, when subjected to cooking at varying time duration. The major fatty acids present in raw sardine were myristic, palmitic, stearic, oleic, eicosapentaenoic acid (EPA) and docosahexaenoic acid (DHA). The dominant fatty acids in sardine curry boiled for $20 \mathrm{~min}$ and $30 \mathrm{~min}$ were lauric acid, myristic acid, oleic acid and linoleic acid which might have leached from the ingredients such as coconut and the cooking oil used for curry preparation. There was a reduction in EPA and DHA in the sardine curry. The leaching of EPA and DHA from sardine pieces into the gravy was negligible. Sardine pieces in curry retained almost half of the EPA and DHA that are found in raw sardine even after boiling for 20 and 30 min respectively.
\end{abstract}

Keywords: Curry, Docosahexaenoic acid, Eicosapentaenoic acid, Fatty acids, Omega 3, Sardine

Fish is a source of protein, essential fatty acids and micronutrients. The $\mathrm{WHO}$ and $\mathrm{FAO}$ recommends per capita consumption of at least $15-20 \mathrm{~kg}$ fish per annum; but the annual per capita consumption of fish in India is only $9.8 \mathrm{~kg}$. About $35 \%$ of Indian population eat fish and derive the health benefits associated with fish fat and protein. The fatty fish normally contains $3-12 \%$ fat which is high in omega 3 fatty acids such as eicosapentaenoic acid (EPA C20:5, n-3), docosahexaenoic acid (DHA C22:6, n-3) and docosapentaenoic acid (DPA C22:5, n-3). DHA and EPA have several health benefits related to cardio-vascular disease, arthritis and bipolar disorder. They are known to cause significant decrease in total and low density lipoprotein (LDL) cholesterol level (Gardner and Kraemer, 1995). DHA plays an important role in brain development and retinal function of the foetus and infants. Recognising the health benefits, the American Heart Association recommends to consume $0.5-1.0 \mathrm{~g} \mathrm{day}^{-1}$ of EPA and DHA.

In India, especially in the south, marine fish plays an important role in the diet of the population. Fish are mainly consumed as fried or curry and at times baked, boiled and steamed. Fish curry is a delicacy, in which, fish are cooked along with spices, tamarind and coconut paste. Cooking is performed by boiling at $100^{\circ} \mathrm{C}$ and the high temperature is expected to cause an adverse effect on fish fat, as the fatty fish contains large proportion of highly unsaturated fatty acids with 5 or 6 double bonds. The unsaturated fatty acids are prone to oxidation during cooking or thermal processing and there is a loss of these health beneficial omega 3 fatty acids.
The goldstripe sardinella, Sardinella gibbosa (Bleeker, 1849 ) is a pelagic fatty fish widely available in Thoothukudi region of Tamil Nadu and it is a good source of omega 3 fatty acids. A few authors have examined changes in the fatty acid composition of processed seafoods (Sanchez-Muniz et al., 1992, Candela et al., 1998, Garcia Arias et al., 2003, Gladyshev et al., 2006, Weber et al., 2008). Aubourg et al. (1990) investigated the fatty acid composition particularly EPA and DHA contents in cooked albacore tuna. Notable effects on fatty acids in shellfish have been reported due to various processing methods (Ghazala et al., 1996). The changes in profile of fatty acid composition of steam cooked tilapia were reported by Dhanapal et al. (2012). The retention of EPA and DHA in fish curry processed by sous vide cook chill and hot filled technologies were 55.4 and $29 \%$, respectively even after 3 months of storage in refrigeration (Shakila et al., 2012). However, most of these studies reported changes in individual fatty acids in processed fish and have not examined the overall effect of different ingredients on the fatty acid profile of the product. This work is undertaken to study the changes in fatty acid profile particularly of omega 3 fatty acids of sardine curry subjected to varying cooking durations, so as to examine the availability of these fatty acids in the final product meant for consumption.

For the experiment, fresh sardine ( $S$. gibbosa) were procured from the fish landing centre of Thoothukudi, Tamil Nadu and brought to the laboratory in iced condition. The fish were washed, descaled, beheaded and degutted. Fish 
curry was prepared as per the standard method widely used in Tamil Nadu, India with the recipe as given in Table 1.

Table 1. Ingredients used for preparation of fish curry

\begin{tabular}{ll}
\hline Ingredients & Quantity \\
\hline Dressed fish & $1 \mathrm{~kg}$ \\
Mustard & $5 \mathrm{~g}$ \\
Cumin seed & $10 \mathrm{~g}$ \\
Fenugreek & $5 \mathrm{~g}$ \\
Onion & $200 \mathrm{~g}$ \\
Garlic & $5 \mathrm{~g}$ \\
Curry leaves & $5 \mathrm{~g}$ \\
Green chillies & $2 \mathrm{Nos}$. \\
Tomatoes & $200 \mathrm{~g}$ \\
Tamarind & $30 \mathrm{~g}$ \\
Chilly powder & $7.5 \mathrm{~g}$ \\
Coriander powder & $10 \mathrm{~g}$ \\
Turmeric powder & $3 \mathrm{~g}$ \\
Salt & $20 \mathrm{~g}$ \\
Coconut & $200 \mathrm{~g}$ \\
Coriander leaves & $15 \mathrm{~g}$ \\
Cooking oil & $90 \mathrm{ml}$ \\
\hline
\end{tabular}

The ingredients used for the curry preparation were obtained from local supermarket. Initially, sunflower oil was heated in a pan and ingredients such as mustard, cumin seeds and fenugreek were added. Finely chopped onion, garlic and curry leaves were then added and fried until onion turned golden brown. Tomatoes ground to fine paste were added and fried well. Spices such as chilly, coriander and turmeric powder were added and cooked. Tamarind pulp was then added along with required quantities of water and salt and the mixture was allowed to boil for $5 \mathrm{~min}$. Dressed fish pieces were then added followed by the addition of finely ground coconut paste, whole green chillies and coriander leaves. The flame was simmered once the curry started boiling. One lot was allowed to boil for $20 \mathrm{~min}$ and another for $30 \mathrm{~min}$. The curry was then allowed to cool sufficiently.

From each lot, samples were drawn as three sub lots as gravy $(\mathrm{G})$, fish piece $(\mathrm{F})$ and gravy with fish $(\mathrm{GF})$ i.e., curry for fatty acid analysis. Fatty acid composition of major ingredients like coconut (C) and sunflower oil (SO) were also analysed to examine the possible leaching effects. The fish lipids from the raw fish and the different sub lots were extracted following the procedure of Folch et al. (1957). Sample (10 g) was homogenised with $30 \mathrm{ml}$ of chloroform:methanol (1:2) and filtered. The impurities were removed by the addition of $0.74 \% \mathrm{KCl}$ followed by separation in a separating funnel. The lower chloroform layer was removed and evaporated to dryness in a rotary flash evaporator (Superfit, Mumbai, India) under a steam of nitrogen. The extracted lipid was used for methylation by Boron tri fluoride (BF3) methanol method (AOAC, 1990). The lipid $(250 \mathrm{mg})$ was taken in a screw capped tube to which $4 \mathrm{ml}$ of $0.5 \mathrm{M}$ methanolic $\mathrm{NaOH}$ was added and refluxed for $10 \mathrm{~min}$. Five $\mathrm{ml}$ of BF3-methanol was then added and refluxed for another $2 \mathrm{~min}$. Saturated sodium chloride was added to separate the saponified fraction. Methyl esters were then separated out by the addition of $2.5 \mathrm{ml}$ of hexane. The upper hexane layer was carefully removed and concentrated to dryness under the steam of nitrogen to $1 \mathrm{ml}$.

Fatty acid composition was determined by gas chromatography technique following the method described by Stephen et al. (2010) with slight modification. Perkin Elmer Autosystem XL Gas Chromatograph fitted with a flame ionisation detector (FID) and a fused silica capillary column (PE-225, $0.25 \mathrm{~mm}$ ID, $30 \mathrm{~m}$ length) was used for the separation. The operating conditions were injector temperature $250^{\circ} \mathrm{C}$ and detector temperature $300^{\circ} \mathrm{C}$. A temperature gradient programme was followed with initial oven temperature set at $70^{\circ} \mathrm{C}$ for $1 \mathrm{~min}$, which was then increased to $180^{\circ} \mathrm{C}$ at the rate of $30^{\circ} \mathrm{C} \mathrm{min}^{-1}$ and to $220^{\circ} \mathrm{C}$ at the rate of $10^{\circ} \mathrm{C} \mathrm{min}{ }^{-1}$. The carrier gas used was nitrogen at 20 psi pressure. Peaks were identified by comparison of their retention times with those of authentic fatty acid standard mixture (Sigma Chemicals Co., Product No. 189-19, St. Louis, USA, 99\% purity) and expressed as peak area percentage.

The experiment was carried out thrice and the average values are presented in the tables. Data analysis was carried out using one way ANOVA with a Duncan post hoc test (SPSS 10 Statistical package) for major fatty acids.

The fatty acid profile of the raw sardine and that of sardine curry processed for 20 and $30 \mathrm{~min}$. are given in Table 2. The major saturated fatty acid (SFA) present in raw sardine were myristic acid C14:0 (7.86\%), palmitic acid C16:0 (28.97\%) and stearic acid C18:0 (6.33\%). Oleic acid $\mathrm{C} 18: 1(7.74 \%)$ is the only major mono unsaturated fatty acid (MUFA). EPA (C20:5 9.61\%) and DHA(C22:6 14.72\%) were the dominant polyunsaturated fatty acids (PUFA). Palmitic acid has been reported to be the major fatty acid in marine fish by many authors (Bandarra et al., 1997; Stephen et al., 2010). In the fish curry (20 min. GF and $30 \mathrm{~min}$. GF), the fatty acid profile was found to be entirely different from that of raw sardine. The major fatty acids were lauric acid C12:0, myristic acid $\mathrm{C} 14: 0$, palmitic acid $\mathrm{C} 16: 0$, stearic acid $\mathrm{C} 18: 0$, oleic acid C18:1 and linoleic acid C18:2 and PUFA C20:5 and C22:6. Such change in fatty acid profile of cook chilled cobia fish curry was earlier reported by Shakila et al. (2012) where the major fatty acids were linoleic, lauric, palmitic and oleic acids. There was a reduction in EPA and DHA in the sardine curry than that of raw fish. The EPA C20:5 in raw fish was $9.61 \%$ which reduced to $2.29 \%$ in GF after $20 \mathrm{~min}$. of cooking, which further reduced to $0.49 \%$ after 30 min. Similarly, the DHA C22:6 in raw sardine $(14.72 \%)$ reduced to $2.86 \%$ in GF after $20 \mathrm{~min}$. and $0.42 \%$ after $30 \mathrm{~min}$. of cooking. This suggested that an increase in cooking duration reduced the availability of health beneficial omega 3 fatty acids, EPA and DHA and increased the imbibition of 
Table 2. Fatty acid composition (\% of total fatty acids) of sardine curry subjected to different cooking durations

\begin{tabular}{llll}
\hline Fatty acid & $\begin{array}{l}\text { Raw fish } \\
(\mathrm{F})\end{array}$ & $\begin{array}{l}\text { Sardine curry } \\
(20 \text { min }) \\
(\mathrm{GF})\end{array}$ & $\begin{array}{l}\text { Sardine curry } \\
(30 \text { min }) \\
(\mathrm{GF})\end{array}$ \\
\hline C8:0 & $\mathrm{ND}$ & $2.68 \pm 0.2$ & $1.14 \pm 0.04$ \\
C10:0 & $\mathrm{ND}$ & $1.41 \pm 0.01$ & $4.15 \pm 0.1$ \\
C12:0 & ND & $9.26 \pm 0.41$ & $23.83 \pm 0.34$ \\
C14:0 & $7.86 \pm 0.15^{\mathrm{a}}$ & $5.28 \pm 0.12^{\mathrm{b}}$ & $12.63 \pm 0.32^{\mathrm{c}}$ \\
C15:0 & $0.58 \pm 0.07$ & $0.32 \pm 0.01$ & $0.32 \pm 0.04$ \\
C16:0 & $28.97 \pm 0.5^{\mathrm{a}}$ & $10.21 \pm 0.13^{\mathrm{b}}$ & $7.49 \pm 0.15^{\mathrm{c}}$ \\
C16:1 & $6.6 \pm 0.38$ & $\mathrm{ND}$ & $\mathrm{ND}$ \\
C17:0 & $2.24 \pm 0.01$ & $\mathrm{ND}$ & $\mathrm{ND}$ \\
C18:0 & $6.33 \pm .004^{\mathrm{a}}$ & $3.56 \pm 0.12^{\mathrm{b}}$ & $1.25 \pm 0.09^{\mathrm{c}}$ \\
C18:1 & $7.74 \pm 0.4^{\mathrm{a}}$ & $25.99 \pm 1.34^{\mathrm{b}}$ & $35.25 \pm 1.04^{\mathrm{c}}$ \\
C18:2 & $2.21 \pm 0.04^{\mathrm{a}}$ & $29.28 \pm 1.13^{\mathrm{b}}$ & $8.43 \pm 0.21^{\mathrm{c}}$ \\
C18:3 & $1.25 \pm 0.01$ & $0.21 \pm 0.02$ & $0.19 \pm 0.01$ \\
C20:1 & $1.9 \pm 0.02$ & ND & ND \\
C20:3 & $1.34 \pm 0.03$ & $0.67 \pm 0.02$ & ND \\
C20:4 & $1.04 \pm 0.03$ & $0.25 \pm 0.01$ & ND \\
C20:5 & $9.61 \pm 0.85^{\mathrm{a}}$ & $2.29 \pm 0.21^{\mathrm{b}}$ & $0.49 \pm 0.01^{\mathrm{c}}$ \\
C22:0 & $0.22 \pm 0.01$ & ND & $0.14 \pm 0.009$ \\
C22:2 & $0.65 \pm 0.02$ & $0.47 \pm 0.01$ & $0.57 \pm 0.00$ \\
C23:0 & $0.45 \pm 0.04$ & $0.33 \pm 0.01$ & ND \\
C22:6 & $14.72 \pm 1.06^{\mathrm{a}}$ & $2.86 \pm 0.18^{\mathrm{b}}$ & $0.42 \pm 0.01^{\mathrm{c}}$ \\
\hline a,b,c Values & bearing different & superscripts in the & same row differ \\
significantly $(\mathrm{p}<0.05) ;$ Only significant differences for major fatty acids \\
are shown & & &
\end{tabular}

the oleic and linoleic acids from the cooking oil and other ingredients. Such reductions in EPA and DHA contents were reported in cook chilled cobia curry (Shakila et al., 2012) and in conventionally heated (at $100^{\circ} \mathrm{C}$ for $20 \mathrm{~min}$ ) seal meat product (Ghazala et al., 1996).

Table 3 gives the comparison of fatty acid profiles of the 20 min processed fish curry (GF), sunflower oil (SO) and coconut paste $(\mathrm{C})$ to examine the leaching of fatty acids. The major proportion of fatty acid in SO were oleic acid (C18:1, 37.36\%) and linoleic acid (C18:2, 57.27\%) whereas in $\mathrm{C}$ were lauric acid (C12:0, 46.02\%) and myristic acid (C14:0, $17.78 \%$ ) This indicates that the lauric acid in the GF had migrated from the coconut paste while the oleic and linoleic acids from the sunflower oil rather than from the gravy. Musaiger and D' Souza (2011) had also reported an increase in the linoleic acid in the curry of pearl spotted rabbit fish.

The distribution of fatty acids in the different components of fish curry boiled for $20 \mathrm{~min}$, such as gravy (G), fish (F) and gravy with fish (GF) in comparison to that of raw sardine was examined (Table 4). The major fatty acids of fish curry (GF) were lauric, (C12:0 21.65\%), oleic (C18:1 $33.69 \%$ ) and linoleic acid (C18:2 29.28\%), which were the main fatty acid components of coconut paste and sunflower
Table 3. Migration of fatty acid ( $\%$ of total fatty acids) in fish curry

\begin{tabular}{|c|c|c|c|}
\hline Fatty acid & $\begin{array}{l}\text { Sardine } \\
\text { curry }(\mathrm{GF})\end{array}$ & $\begin{array}{l}\text { Sunflower } \\
\text { oil (SO) }\end{array}$ & $\begin{array}{l}\text { Coconut } \\
\text { paste }(\mathrm{C})\end{array}$ \\
\hline C8:0 & $2.68 \pm 0.2$ & ND & $9.38 \pm 0.85$ \\
\hline C10:0 & $1.41 \pm 0.01$ & ND & $6.42 \pm 0.49$ \\
\hline C12:0 & $9.26 \pm 0.41$ & ND & $46.02 \pm 1.97$ \\
\hline C14:0 & $5.28 \pm 0.12$ & $0.07 \pm 0.00$ & $17.78 \pm 1.47$ \\
\hline C15:0 & $0.32 \pm 0.01$ & ND & ND \\
\hline C16:0 & $10.21 \pm 0.13$ & ND & $8.06 \pm 0.85$ \\
\hline C17:0 & ND & ND & $0.02 \pm 0.00$ \\
\hline C18:0 & $3.56 \pm 0.12$ & ND & $2.91 \pm 0.08$ \\
\hline C18:1 & $25.99 \pm 1.34$ & $37.36 \pm 1.59$ & $8.24 \pm 0.91$ \\
\hline C18:2 & $29.28 \pm 1.13$ & $57.27 \pm 2.05$ & $0.06 \pm 0.01$ \\
\hline C18:3 & $0.21 \pm 0.02$ & ND & ND \\
\hline C20:0 & ND & $0.87 \pm 0.03$ & $0.06 \pm 0.01$ \\
\hline C20:1 & ND & ND & $0.03 \pm 0.00$ \\
\hline C20:3 & $0.67 \pm 0.02$ & ND & ND \\
\hline C20:4 & $0.25 \pm 0.01$ & ND & ND \\
\hline C20:5 & $2.29 \pm 0.21$ & ND & ND \\
\hline C22:1 & ND & 0.67 & ND \\
\hline $\mathrm{C} 22: 2$ & $0.47 \pm 0.01$ & ND & ND \\
\hline C23:0 & $0.33 \pm 0.01$ & ND & ND \\
\hline $\mathrm{C} 22: 6$ & $2.86 \pm 0.18$ & ND & ND \\
\hline
\end{tabular}

Table 4. Distribution of fatty acids ( $\%$ of total fatty acids) in sardine curry

\begin{tabular}{lllll}
\hline $\begin{array}{l}\text { Fatty } \\
\text { acid }\end{array}$ & Raw fish & $\begin{array}{l}\text { Sardine } \\
\text { curry }(\mathrm{GF})\end{array}$ & $\begin{array}{l}\text { Gravy } \\
(\mathrm{G})\end{array}$ & $\begin{array}{l}\text { Sardine } \\
\text { piece (F) }\end{array}$ \\
\hline $\mathrm{C} 8: 0$ & $\mathrm{ND}$ & $2.68 \pm 0.2$ & $3.7 \pm 0.32$ & $1.87 \pm 0.14$ \\
$\mathrm{C} 10: 0$ & $\mathrm{ND}$ & $1.41 \pm 0.01$ & $2.83 \pm 0.18$ & $0.97 \pm 0.01$ \\
$\mathrm{C} 12: 0$ & $\mathrm{ND}$ & $9.26 \pm 0.41$ & $21.65 \pm 4.58$ & $2.83 \pm 0.25$ \\
$\mathrm{C} 14: 0$ & $7.86 \pm 0.15$ & $5.28 \pm 0.12$ & $2.21 \pm 0.09$ & $6.96 \pm 0.74$ \\
$\mathrm{C} 15: 0$ & $0.58 \pm 0.07$ & $0.32 \pm 0.01$ & $\mathrm{ND}$ & $\mathrm{ND}$ \\
$\mathrm{C} 16: 0$ & $28.97 \pm 0.5$ & $10.21 \pm 0.13$ & $10.05 \pm 1.10$ & $21.17 \pm 0.69$ \\
$\mathrm{C} 16: 1$ & $6.6 \pm 0.38$ & $\mathrm{ND}$ & $\mathrm{ND}$ & $4.63 \pm 0.08$ \\
$\mathrm{C} 17: 0$ & $2.24 \pm 0.01$ & $\mathrm{ND}$ & $\mathrm{ND}$ & $1.26 \pm 0.02$ \\
$\mathrm{C} 18: 0$ & $6.33 \pm .004$ & $3.56 \pm 0.12$ & $\mathrm{ND}$ & $5.08 \pm 0.57$ \\
$\mathrm{C} 18: 1$ & $7.74 \pm 0.4$ & $25.99 \pm 1.34$ & $33.69 \pm 1.58$ & $7.87 \pm 0.64$ \\
$\mathrm{C} 18: 2$ & $2.21 \pm 0.04$ & $29.28 \pm 1.13$ & $11.34 \pm 0.56$ & $7.02 \pm 0.29$ \\
$\mathrm{C} 18: 3$ & $1.25 \pm 0.01$ & $0.21 \pm 0.02$ & $\mathrm{ND}$ & $0.42 \pm 0.03$ \\
$\mathrm{C} 20: 1$ & $1.9 \pm 0.02$ & $\mathrm{ND}$ & $\mathrm{ND}$ & $0.32 \pm 0.01$ \\
$\mathrm{C} 20: 3$ & $1.34 \pm 0.03$ & $0.67 \pm 0.02$ & $\mathrm{ND}$ & $0.52 \pm 0.04$ \\
$\mathrm{C} 20: 4$ & $1.04 \pm 0.03$ & $0.25 \pm 0.01$ & $\mathrm{ND}$ & $\mathrm{ND}$ \\
$\mathrm{C} 20: 5$ & $9.61 \pm 0.85$ & $2.29 \pm 0.21$ & $\mathrm{ND}$ & $5.42 \pm 0.09$ \\
$\mathrm{C} 22: 0$ & $0.22 \pm 0.01$ & $\mathrm{ND}$ & $\mathrm{ND}$ & $0.5 \pm 0.03$ \\
$\mathrm{C} 22: 2$ & $0.65 \pm 0.02$ & $0.47 \pm 0.01$ & $\mathrm{ND}$ & $0.15 \pm 0.00$ \\
$\mathrm{C} 23: 0$ & $0.45 \pm 0.04$ & $0.33 \pm 0.01$ & ND & $0.6 \pm 0.02$ \\
$\mathrm{C} 22: 6$ & $14.72 \pm 1.06$ & $2.86 \pm 0.18$ & $0.09 \pm 0.00$ & $7.49 \pm 0.16$ \\
& & & &
\end{tabular}

oil. There was no migration of EPA and DHA from fish (F) into the gravy $(\mathrm{G})$. The fatty acid profile of $\mathrm{F}$ was similar to that of raw fish with the presence of $\mathrm{C} 16: 021.17 \%, \mathrm{C} 18: 1$ 7.87\%, C18:2 7.02 \%, C20:5 5.42\% and C22:6 7.49\%. Fish 
steaks had retained $56 \%$ of EPA and $51 \%$ of DHA after processing. The fatty acid profile of GF however had presence of fatty acids derived from sunflower oil and coconut paste in addition to those found in fish.

Fish curry had a fatty acid profile partially similar to that of raw sardine, in addition to certain fatty acids derived from the cooking oil and ingredients. The EPA and DHA content got reduced with cooking duration $(56 \%$ of EPA and $51 \%$ of DHA). Desired fatty acid composition in the final product (fish curry) can be derived by the addition of suitable ingredients/oil. Fish steaks with less gravy can be consumed to harness the maximum health benefits of omega 3 fatty acids.

\section{References}

AOAC 1995. Official methods of analysis, $16^{\text {th }}$ edn. Association of Official Analytical Chemists, Washington, DC, USA.

Aubourg, P. A., Sotelo, G. C. and Gallardo, M. J. 1990. Changes in fish lipids and fill oils of albacore (Thunnus alalunga) during canning and storage. J. Agri. Food Chem., 38(3): 809-812.

Bandarra, N. M., Batista, I., Nunes, M. L., Empis, J. M. and Christie, W. W. 1997. Seasonal variation in lipid composition of sardine (Sardina pilchardus). J. Food Sci., 62: 40-41.

Candella, M., Astiasaran, I. and Bello, J. 1998. Deep fat frying modifies high fat fish lipid fraction. J. Agric. Food Chem., 46: 2793-2796.

Dhanapal, K., Reddy, G. V. S., Naik, B. B., Venkateswarlu, G., Reddy, A. R. and Basu, S. 2012. Effect of cooking on physical, biochemical, bacteriological characteristics and fatty acid profile of Tilapia (Oreochromis mossambicus) fish steaks. Arch. Appl. Sci. Res., 4(2): 1142-1149.

Folch, J., Lees, M. and Stanley, G. H. S. 1957. A simple method for the isolation and purification of total lipids from animal tissues. J. Biol. Chem., 226(1): 497-509.
Garcia-Arias, M., Pontes, E. A., Garcia Linares, M. C., Garcia Fernandez, M. C. and Sanchez Muniz, F. J. 2003. Cookingfreezing-reheating (CFR) of sardine (Sardina pilchardus) fillets. Effect of different cooking and reheating procedures on the proximate and fatty acid compositions. Food Chem., 83: 349-356.

Gardner, C. D. and Kraemer, H. C. 1995. Monounsaturated versus polyunsaturated dietary fat and serum lipids. Arteriosclerosis Thrombosis Vascular Biol., 15(11): 1917-27.

Ghazala, S., Aucoin, J. and Alkanani, T. 1996. Pasteurisation effect on fatty acid stability in a sous vide product containing seal meat. J. Food Sci., 61(3): 520-523.

Gladyshev, M. I., Nadezhda, N., Sushchi., Gubanenko, G. A., Demirchieva, S. M. and Kalachova, G. S. 2006. Effect of boiling and frying on the content of essential fatty acids in muscle tissue of four fish species. Food Chem., 101: $1694-1700$.

Muaiger, A. O. and D'Souza, R. 2011. Fatty acid profile of raw and cooked fish consumed in Bahrain. Afr. J. Food Sci., 5(4): 213-218.

Sanchez- Muniz, F. J., Viejo, J. M. and Medina, R. 1992. Deep frying of sardines in different culinary fats. Changes in fatty acid composition of sardines and frying fats. J. Agri. Food Chem., 40: 2252-2256.

Shakila, R. J., Edwin Raj, B. and Felix, N. 2012. Quality and safety of fish curry processed by sous vide cook chilled and hot filled technology process during refrigerated storage. Food Sci. Technol. Inter., 18(3): 261-269.

Stephen, N. M., JeyaShakila, R., Jeyasekaran, G. and Sukumar, D. 2010. Effect of different types of heat processing on changes in tuna. J. Food Sci. Technol., 47(2): 174-181.

Weber, J., Bochi, V. C., Ribeiro, C. P., Victoria, A. D. M. and Emanuelli, T. 2008. Effect of different cooking methods on the oxidation, proximate and fatty acid composition of silver catfish (Rhamdia quelen) fillets. Food Chem., 106: 140-146. 